Saeculum Christianum

vol. XXIV (2017)

pp. $66-72$

\author{
JOLANTA M. MARSZALSKA
}

Faculty of Historical and Social Sciences

Cardinal Stefan Wyszyński University in Warsaw

\title{
CLOISTRAL SCRIPTORIA AND MEDIEVAL CISTERCIAN LEGISLATION ON THE BOOK
}

Between the second half of the $10^{\text {th }}$ century and the first half of the $13^{\text {th }}$ century, the civilizational and cultural output of early Polish history saw new and important contributions in the fields of material and intellectual culture, along with the budding system of cathedral and cloistral schools, scriptoria, and - above all - the emergence of the book. The first books came to the early Piast state in the second half of the $10^{\text {th }}$ century, likely from the Benedictine scriptoria in Bavaria, Saxony, Rhineland, and Lorraine. These first manuscripts were codices containing Biblical texts and liturgical books indispensible for celebrating the Mass, which were imported along with church paraments for the newly sprung centers of Christian worship. Among those manuscripts were Lectionaries for the celebration of the Mass, greatly esteemed as literal embodiments of the Word of God, and Evangeliaries (also known as periscopes) containing excerpts from the Gospels arranged in accordance with the ecclesiastical year.

Apart from the Benedictine Order, it was the Cistercian monks - invited to Poland in the 1140s and settled in the Little Polish town of Jędrzejów - that played the major role in the development of medieval handwritten book culture in Poland. Over the years, the literature penned in the cloistral scriptoria operating at the 26 Cistercian monasteries established in Poland between the mid- $12^{\text {th }}$ and the mid- $14^{\text {th }}$ century was an important facet of monastic life and its evolution. Rewriting, copying, and illuminating handwritten texts in the Early and High Middle Ages constituted a duty and inherent modus vitae of Benedictine monks. The Regula Sancti Benedicti is the fundamental and paramount monastic code of precepts, determining the cloistral life of the Benedictine, Cistercian, and Camaldolese monks, and while it does not strictly rule on books or libraries, it nonetheless addresses them extensively. In his book, St. Benedict of Nursia clearly prescribes the reading hours for monks during Lent, and regulates the loan of codices from cloistral library. "[...] During Lent they should spend the morning reading until the end of the third hour, and then they should work on the tasks assigned them until the end of the tenth hour. During Lent they should all be given a book from the library which they should read from cover to cover. These books should be handed out at the beginning of Lent [...]". . Later on in book 48 of the Rule, St. Benedict adds, "[...] On Sundays they should all spend time reading, apart from those who have been

St. Benedict of Nursia, The Rule of Benedict, trans. C. White, London 2008, chapter 48, p. 118. 
assigned various tasks"2. The above quotation clearly indicates that St. Benedict projected that each cloister would have its own scriptorium and a library (at least a small one) of codices, without which any monastic community would find it difficult to function. Pursuant to St. Benedict's recommendations, Benedictine and Cistercian monks were to spend time reading at specific hours of the day throughout the year. St. Benedict saw devout readership and meditation as a means that would bring monks closer to God, since according to the Rule, the lone goal of monastic life was to seek out God in every facet of existence. The book is also mentioned in the earliest Cistercian legislation. Over the course of ten centuries, books have played an imperative role in monastic life. They were indispensible in the fulfillment of the prescribed lectio Divina, i.e. in liturgy, prayers, spiritual exercises, Biblical studies and exegesis, interpretations of the Rule, statuses, consuetudines, spiritual betterment and perfection of the soul (reading martyrology, vitae partum, and ascetic literature), as well as sermons. The precepts determining the establishment of new Cistercian cloisters necessitated the parent monastery to provide the monks delegated to the new coenobium with at least nine basic and indispensible books: the Missal, the Rule, the Liber usuum, the Psalter, the Hymnal, the Collectary, the Lectionary, the Antiphonary, and the Gradual: "[...] duodecim monachii cum abbate terciodecimo ad coenobia nova transimittantur: nec tamen illuc destinentur donec locus libris domibus et necessariis apretur, libris dumtaxit missali, Regula, libro usuum, psalterio, hymnario, collectane, ionario, anthiphonario, gradali, regula, missali [...]”'

In the early stage of their development, it was also the book of precepts that were vital in the regulation of each monastery as an independent entity, including the Rule and the Liber usuum, as well as liturgical codices for the celebration of the daily Mass. In time, the number of essential books was limited to seven: the Psalter, the Hymnal, the Lectionary, the Collectary, the Gradual, the Rule, and the Missal: "[...] de construendis abbatiis: Non mittendum esse abbatem novum in locum novellum sine monachis ad minus XII-cim, nec sine libris istis: psalterio, hymnario, collectane, antiphonario, gradali, regula, missali [...]"4.

The Cistercian legislators prescribed an rigid set of essential books to be included in the inventory of each cloister. These were the Missal, the Epistolary, the Collectary, the Gradual, the Antiphonary, the Hymnal, the Psalter, the Lectionary, and the Calendar ${ }^{5}$. Over time, the Cistercian libraries began to collect books that were essential for the development of the spiritual and intellectual life of their monks. The various precepts on rewriting, copying, and illuminating the books held in the cloistral scriptoria date back to this very period. The legislators explicitly and strictly regulated who could be entrusted with these important tasks. One of the rules stated that monks, novices, and abbots alike were prohibited from writing (creating) books, save for copying them, unless the said creative activity was commissioned by the General Chapter: "[...] nulli licea abbati nec monacho nec novotio libros facere, nisi forte cuiquam id in generali abbatum capitulo concessum fuerit”.

\footnotetext{
Ibidem, p. 179.

Statuta Capitulorum generalium ordinis Cisterciensis ab anno 1116 ad annum 1786, published by J.M. Canivez, vol.1, Louvain 1933-1941, no. 12, p. 15.

4 Ibidem, vol. 1, no. 9, p. 12.

E. Potkowski, Kultura piśmienna cystersów, in: Pelplin. 725 rocznica powstania opactwa cysterskiego. Kulturotwórcza rola cystersów na Kociewiu, ed. D.A. Dekański, Pelplin-Tczew 2002, pp. 87-89.

6 Statuta Capitulorum generalium ordinis Cisterciensis ab anno 1116 ad annum 1786, published by J.M. Canivez, vol.1, no. 58, p. 26.
} 
Such views were also expressed by St. Bernard of Clairvausx in one of his earliest works, Apologia ad Guilelmum. According to the Cistercian legislation at the time, and above all in line with the teachings of St. Bernard, the great advocate of the ascetic Cistercian art, the books were not to be decorated, and their bindings were to be devoid of silver, golden or gilded clasps. Similar decisions were issued for the illumination of codices, which were deemed redundant and distracting to the praying Cistercian monks. According to St. Bernard, the idea of beauty as simplicity essentially implied that internal beauty far surpasses external ornamentation, and that sensual beauty - while not erroneous in its own right - occurs solely as a manifestation of the spirit ${ }^{7}$. The surviving records of the general chapters of the Cistercian Order stipulate that scriptoria should be furnished simply and moderately, adding that the monks working on the manuscripts should do so in silence: "[...] in omnibus scriptoriis ubicumque ex consuetudine monachi scribunt, silentium teneatur sicut in claustro [...]"8. Furthermore, scribes were not to rewrite or read books outside of the prescribed hours: "[...] scriptores extra terminos non scribant, non libros legunt, ne hostiae fiant [..."'". In the Late Middle Ages, Cistercian monks were obliged to read or listen to as many as 50 volumes of texts (each approximately 300 pages long) annually as part of the lectio divina. Such rulings rendered the work of copyists particularly important ${ }^{10}$. Cistercians were required to piously read and study the Scripture, patristics, Hymnals, and books of customs (libri usuum), which were essential in recording all changes to the Rule and liturgy. One testament to the weight of the Cistercian cloister scribes was their exemption by the General Chapter from other monastic duties performed for their respective monasteries, coupled with dispensation from prescribed rest in favor of additional work (if so required). A case in point can be found in the Himmerod monastery in Rhineland, where scribes would labor over manuscripts at night while the rest of the monks observed the prescribed sleeping hours ${ }^{11}$.

Treatises and books became an inseparable attribute in the daily pursuit of St. Benedict's dictum, ora et labora, in monastic life. Regardless of their size, location, founder, and endowment, the Cistercian cloisters founded in the Kingdom of Poland were supplied with their own scriptoria and, later on, libraries. As mentioned above, one of the basic ways to found new Cistercian book collections was their provision with liturgical books received from the parent monastery. Their number and variety were scrupulously enumerated ${ }^{12}$. The aforementioned statutes of the Cistercian general chapter, dated 1134, stated that, "Twelve monks with a thirteenth as abbot are sent out to the new monastery, however they are not to be sent there until the monastery is provided with books, houses, and other necessities, the Rule, training books, the Psalter, the Hymnal, the Collectary, along with a dormitory, a visiting cell, a door-keeper, and all items of earthly life, so that they could settle there in

\footnotetext{
7 L. Wetesko, Średniowieczna architektura i sztuka w kręgu zakonu cystersów, in: Monasticon Cisterciense poloniae, vol. 1, eds. A.M. Wyrwa, J. Strzelczyk, K. Kaczmarek, Poznań 1999, pp. 216-217.

8 Canivez, Statuta Capitulorum generalium ordinis Cisterciensis ab anno 1116 ad annum 1786, published by J.M. Canivez, vol. 1, no. 85, p. 32.

9 Ibidem, vol. 1, no. 31, p. 58.

10 Ibidem. See also: A. Schneider, Skriptorium und Bibliothek der Cistercienser abtei Himmerod in Rheinland zur Geschichte klosterlichen Bibliothekswesens im Mittelalter, "Bulletin of the John Rylands Library", 35/1952, no. 1, p. 155.

11 Ibidem.

12 T. Manteuffel, Rola cystersów w Polsce w wieku XII, "Przegląd Historyczny”, 41/1950, p. 181; H. Szwejkowska, Biblioteka klasztoru cysterek $w$ Trzebnicy, Wrocław 1955, pp. 37-38.
} 
accordance with the Rule"13. Point 85 of the aforementioned General Chapter regulated the foundation and organization of scriptoria in the respective branch cloisters to render them independent in copying the books received from the parent monastery ${ }^{14}$. In turn, the $17^{\text {th }}$ statute of the Cistercian General Chapter, dated 1212, stipulated that the monks at each cloister be equipped with a minimum of nine codices, among them the Missal, the Gradual, the Psalter, the Hymnal, the Lectionary, the Antiphonary, the Calendar, the Rule, and the Constitutions. The subsequent development of each library largely depended on whether a given cloister had its own scriptorium that wrote codices for the abbey, thus enabling its monks expand theological and philosophical knowledge.

Moreover, the Cistercian chapters recommended that legal texts be extracted from the cloistral armaria, e.g. the Corpus canonum and the Decretum Gratiani, given that their presence in a common armarium could misguide monks, since such legal codices contained contradictory canons that were to be interpreted and adjudicated upon solely by competent legal experts. Setting the Decretum Gratiani and the Corpus canonum aside from the common armaria was also a preventive measure that minimized potential erroneous interpretations and unsubstantiated disputes between legally incompetent Cistercian monks. "[...] Liber qui dicitur Corpus canonum et Decreta Gratiani apud eos qui habuerint secretius custodiantur, ut cum opus fuerit proferantur. In communi armario non resident, propter varios qui inde possunt provenire errors", stated the rule, adding that, "liber qui dicitur Corpus canonum et decreta Gratiani in communi armario non ponantur"15. The above precept essentially instituted a ban on any books whose erroneous interpretation could foment discord within the enclosed community. Several centuries later, a similar ban was instituted on the books inconsistent with the accepted Catholic doctrine (the so-called prohibita).

In large Benedictine and Cistercian monasteries, special rooms were allocated solely for the purposes of the copyists" "workshop", which were customarily referred to as scriptoria. These rooms were furnished with pulpits for copyists, which were later accompanied by chains protecting the copied codices from theft. The copied codices were stored in special bookcases, known as armaria. These storages were of particular importance for the copyists and users of rewritten books. As a rule, each monastery would be equipped with several armaria, including the scriptorium proper, the adjacent library, the sacristy, the treasury, the choir, the abbot's cell, the gallery, and the refectory. The cloistral copyists were responsible for preparing the parchment for the copied book, dividing it in folio into columns, preparing the ink and other necessary tools (style, quill, reed pen, purnice). It should be noted that, aside from the copied Biblical texts, excerpts from patrisctic treatises, rules of monastic life, or liturgical books, the cloistral scriptoria also held the records of a given monastery's foundation and endowment. The scribes commissioned with copying a manuscript did so in accordance with the principles of diplomatics. Thus, the cloistral scriptorium was a platform

\footnotetext{
13 Canivez, Statuta Capitulorum Ordinis Cisterciensis ab anno 1116 ad annum 1786, vol. 1, no. 85, p. 12; J.M. Marszalska, Biblioteka opactwa cystersów w Szczyrzycu do końca XIX stulecia. Dziedzictwo wieków, Tarnów 2007, p. 13; A.M. Wyrwa, Rozprzestrzenianie się cystersów w Europie Zachodniej i na ziemiach polskich, in: Cystersi w kulturze średniowiecznej Europy, ed. J. Strzelczyk, Poznań 1992, p. 27; P. Rybandt, Średniowieczne opactwo cystersów w Rudach, Wrocław 1977, p. 98.

14 K. Bobowski, Skryptorium dokumentowe klasztoru cystersów w Dargunie do końca XIII wieku, Wrocław 1991, pp. 7-8.

15 Ibidem, vol. 1, no. 7, p. 108.
} 
for the meeting of ars dictandi and ars scribendi. In his commentary to Peter Lombard's Sentences, the Franciscan theologian and philosopher, St. Bonaventure, classified four modes of writing, i.e. four types of writers: the copyist (scriptor), whose chief responsibility involved rewriting the texts of others without any commentary or changes; the compiler (compilator), who compiled texts by different authors; the commentator (commentator), also known as the glosser, tasked with rewriting the texts of other and providing them with his own remarks and commentaries; and the author (auctor), who wrote his own texts, using those of others solely to corroborate his own ruminations ${ }^{16}$. Each of the aforementioned contributed their work and skills to the budding written culture of medieval Europe (and, by extension, Poland).

Over time, both the cloistral scriptoria and the codex-filled libraries became part and parcel of monastic infrastructure, as testified by the known Latin dictum at the time, which originated at the Benedictine monastery of Sankt Gallen: "Claustrum sine armario est quasi castrum sine armamentario", (A cloister without a library is like a castle without an armory $)^{17}$. This apt adage also referred to the first handwritten codices penned at the Benedictine and Cistercian monasteries in Poland. The copied theological treatises, legal texts, medical recipes, legal formulae, and philosophical maxims were indispensible to the medieval education at cathedral and cloistral schools. In the Middle Ages, knowledge was derived not only by copying Biblical and theological texts (essential in monastic life) but also from the first yearbooks, hagiographies, or monastery chronicles, which laid the foundation for a more comprehensive perception of the surrounding world.

The thematic content of the primary cloistral book collection usually encompassed the following: the (invariably prominent) Bible, along with the attendant concordances and commentaries; patristic treatises used in teaching Church history in the first ages of Christianity; speculative theology; ascetic and mystical writings; liturgics; hagiography and the lives of the saints, which - in a way - constituted the foundation of Church history; philosophy (indispensible in monastic education), canonical and civil law, and broadly defined natural and medical sciences (astronomy, astrology, geometry). Content-wise, the books copied at the cloistral scriptoria, introducing monks to the full complexity of the phenomena and changes occurring in the surrounding world.

Apart from the reproduction of liturgical texts and memorative libri vivorum et mortuorum, the Cistercian scriptoria also saw the edition of the running administrative and economic records of a given monastery. Working in the silence of the scriptorium, monks would edit the monastery yearbooks, obituaries, chronicles, financial documents tied to the endowment of their respective monasteries, as well as rhymed epitaphs and original literary and historiographic pieces ${ }^{18}$. They contained notes of daily life outside the enclosure, the names and functions of individual friars, notes of watershed events taking place away from the monastery, and mentions of natural disasters (floods, fires, epidemics) in the surrounding areas, along with the incurred losses. Also recorded were the visits of illustrious guests (princes, monarchs) to the monastery - in short, anything and everything that the monk encountered and considered important in the span of his monastic life. The surviving

\footnotetext{
16 E. Potkowski, Pisarz i jego dzieło w średniowiecznym społeczeństwie, Warszawa 1997, pp. 306-307.

17 K. Głombiowski, H. Szwejkowska, Książka i biblioteka w starożytności i średniowieczu, Warszawa 1979, pp. 100-101.

18 K. Bobowski, op. cit., pp. 18-19.
} 
monastery chronicles provide invaluable insight to the sensibilities and interpersonal relations of cloistered communities, as well as their relations with the immediate surroundings, and manifestations of medieval worldviews. A noteworthy example of a monastery chronicle comes with the thoroughly unique Liber fundationis claustri Sanctae Mariae Virginis in Henrichow, a chronicle of the Cistercian monastery in the Silesian town of Henryków (est. 1227), known in Polish historiography as the Book of Henryków, and written by Abbot Peter of Henryków in 1268. Interestingly, the book contains the first-ever sentence written in Polish (Day, ut ia pobrusa, a ti poziwai). While in the case of many handwritten codices penned in the cloistral scriptoria, the writer, copyist, or illuminator would customarily remain anonymous, the "authorship" of monastery chronicles is easier to establish thanks to a number of signed entries or the fact that they would usually be penned by the local abbot. It should also be pointed out that the production of records (such as monastery chronicles) was classified as mundane writing, and as such it did not touch on the sacrum, i.e. the Scripture, in the face of which individual humans would remain anonymous.

Oftentimes, the respective fragments of these chronicles would be rewritten by different copyists, who did not always sign them. It should be stressed that, back in the $5^{\text {th }}$ and $6^{\text {th }}$ century, Magnus Aurelius Cassiodorus (aka Cassiodorus), who first served as a chancellor at the court of King Theoderic the Great, and subsequently joined the ranks of the Benedictine Order, founding one of its best scriptoria at the monastery of Vivarium in Calabria, emphasized the meaning of the very act of writing in his Institutiones, but he did so without insisting that the writer/copyist insert their name in their work. As per Cassiodorus ${ }^{19}$, since the writer transmitted the words of the Scripture, the cloistral scribe was but an undeserving apprentice of God, and thus it was unseemly for him to put his name next to that of God's. In the same vein, Alcuin (ca. 730-804) ${ }^{20}$ praised copyist for their meticulous multiplication of texts, at the same time stressing that they are merely tools in the hands of God; similarly, Rabanus Maurus, abbot of the Benedictine monastery in Fulda ${ }^{21}$, referred to rewriting and copying as a holy and sacred activity, a work more worthy of reward than any other. Similar statements, testifying to the medieval monastic culture, can be traced in a number of writings. ${ }^{22}$ The words of Cassiodorus and his contemporaries were not alien to Polish Benedictine and Cistercian monasteries, whose anonymous copyists labored over parchment-laden pulpits in complete silence and with undivided attention. As best summarized by the outstanding Swedish historian of the book, Svend Dahl, "in the quiet writing room, the scriptorium, where the noises of the world did not penetrate and where life was controlled by the strong bonds of regulation, monks and nuns applied themselves to their task of copying for the glory of God. The labor of years was expended on many of the old manuscripts [...] and it would scarcely have been possible to complete such a work except in a monastery where life was lived "sub specie aeternitatis." Several monks often worked together on the same codex, each taking a separate section" 23 .

19 K. Głombiowski, H. Szwejkowska, op. cit., p. 101-103.

20 Ibidem.

21 Ibidem.

22 Miłość nauki a pragnienie Boga, trans. M. Borkowska, in: Źródła monastyczne. Opracowania, vol. 14, ed. J.A. Spież, Kraków 1997.

${ }^{23}$ S. Dahl, History of the Book, New York 1958, p. 57. 


\section{Cloistral scriptoria and medieval Cistercian legislation on the book Summary}

The earliest books in the early Piast state in the second half of the $10^{\text {th }}$ century were likely imported from the Benedictine scriptoria in Bavaria, Saxony, Rhineland, and Lorraine. These manuscripts contained Biblical texts and liturgical books indispensible for celebrating the Mass. The $12^{\text {th }}$-century precepts determining the establishment of new Cistercian cloisters necessitated the parent monastery to provide the monks delegated to the new coenobium with at least nine basic and indispensible books: the Missal, the Epistolary, the Gospels, the Gradual, the Antiphonary, the Hymnal, the Psalter, the Lectionary, and the Calendar. The said regulations rendered the work of copyists particularly important. One testament to the weight of the Cistercian cloister scribes was their exemption by the General Chapter from other monastic duties performed for their respective monasteries, coupled with dispensation from prescribed rest in favor of additional work (if so required). Apart from the reproduction of liturgical texts and memorative libri vivorum et mortuorum, the Cistercian scriptoria also saw the edition of the running administrative and economic records of a given monastery. Working in the silence of the scriptorium, monks would edit the cloistral yearbooks, obituaries, monastery chronicles, and rhymed epitaphs. They contained notes of daily life outside the enclosure, the names and functions of individual friars, notes of watershed events taking place away from the monastery, and mentions of natural disasters (floods, fires, epidemics) in the surrounding areas, along with the incurred losses. The surviving monastery chronicles provide invaluable insight to the sensibilities and interpersonal relations of cloistered communities, as well as their relations with the immediate surroundings, and manifestations of medieval worldviews.

Keywords: monastery, scriptorium, manuscript code, Benedict, Cistercian

Note on the Author: prof. zw. dr hab. Jolanta M. Marszalska is a full professor at the Institute of Historical Sciences of the Faculty of Historical and Social Sciences at the Cardinal Stefan Wyszyński University in Warsaw. Her research interests include Old Polish literary culture, monasticism, cloistral libraries of the Benedictines, Cistercians, Bernardines, and Discalced Carmelites, as well as the historical book collection of the Dioceses of Tarnów and Płock, and the history of Polish aristocratic families. 